\title{
THE TRAINING AND QUALIFICATIONS OF THE FOREST ENGINEER IN QUEBEC ${ }^{1}$
}

\section{BY MARCEL LORTIE 2}

Oxf. $945.31(714)$

After the different papers you have heard on economic planning and land management, you are undoubtedly wondering what is the role of the forest engineer in this field? In order to reply to this question, it is first best to study the training of the forest engineer, it will then be easier to determine his qualifications. In other words the study of the area of his knowledge permits a definition of the role which has evolved for him.

\section{The Training}

The training of a forest engineer can be discussed from several points of view, but we will limit ourselves to a consideration of the professional training common to most of us, i.e., the university training. There are also special studies of techniques that certain employers give to their employees; there are also extension and post-graduate courses. However, we must consider these courses as being a complement to the university training already received. Also, without giving any discredit to the formation given in other university centres, we will concern ourselves with that which constitutes the basic training common to most of us, that given at the Faculty of Forestry and Geodesy at Laval University. Without doubt, in the opinion of some I will be a victim of bias or prejudice. I don't ask you to excuse me in advance but just give to me that indulgence which you would ask for yourself.

The most common access to the profession of forestry in Quebec is through the Faculty of Forestry and Geodesy of Laval University. This course, as you know, is of four years duration, plus a preparatory one for certain people. This preparation class is rendered necessary by the absence of a real pre-university teaching. The changes which are starting to appear in the world of education in Quebec could, in a few years, cause the end of this preparatory period and even part of the first year. The courses which are given in this period would find their place in the ranks of the Institutes foreseen by the authors of the Parent Report (1965).

However, we are speaking of the Faculty as it exists today with its current curriculum. If one generally admits that there is change in the world it is also necessary to accept the fact that the Faculty of Forestry and Geodesy is also in the course of constant change. For example it is necessary to mention that there are now 37 career professors without counting lecturers, and there are more than 450 regular students in forestry and surveying and close to 60 students studying towards a master or a doctor degree.

In the last few months we have seen the Faculty change its name. By a decision of the University Counsel the Faculty of Surveying and Forest Engineering became the Faculty of Forestry and Geodesy.

\footnotetext{
${ }^{1}$ Talk given to the Annual Meeting of the Quebec Corporation of Forest Engineers, Quebec City, October, 1966. Translated by G. F. Weetman.

${ }^{2}$ Associate Professor and Director of the Department of Management and Silviculture, Faculty of Forestry and Geodesy, Laval University, Quebec.
} 
Here are the implications of this change as published in the calendar of the Faculty:

"This decision of the University Counsel resulted from the necessity of translating as closely as possible, in a name for the faculty, which reffects at all levels, the nature of the teaching and the research currently carried out in the Faculty".

Also, being aware of the importance of giving to students a complete theoretical training and an adequate practical training in such fields as management, silviculture, logging and photogrammetry, the professors of the Faculty, with the help of the Minister of Lands and Forests of the province, have succeeded in setting up in 1966 the first summer course of 3 months' duration for those students who are entering the last year of the course. Even if this preliminary experience has underlined certain problems of organization, even if the students have not been completely delighted, the general idea seems to have been a success. The majority of the students, if not all, have been able to touch upon several problems which formerly they would not even have thought of if they had returned to cruising for the companies.

For teaching, the Montmorency Forest represents a very close reality to actual forestry practise. The professors of the Faculty inspired by modern methods want to show that the students can perceive the problems which develop on industrial forestry operations. The methods of exploitation applied to the Montmorency Forest are as closely as possible analogous to those of industry. They include, in particular, interpretation of aerial photography, inventory, preparation of a management plan, a program of cutting, the establishment on the ground of cutting areas, hauling roads and trucking roads, and locations of piles, the cut of wood, the skidding and transportation of wood and the sale of wood. The students are invited to participate in the different phases of the preparation and execution, if not as workers then as observers and analysts, all in obvious preparation for their work as forest engineers.

As well as these changes, the University Counsel, by a decision dated September 1966, has accorded to the Faculty of Forestry and Geodesy a new organization based upon the necessity of more specialized training. Allow me some explanation of this subject. In the course of the 6th World Congress of Forestry, it was said:

"One speaks of progress in chemistry, physics, mathematics, engineering, biology, and economics and one speaks of the importance of these for forest science. It thus becomes important that the professors be up to date in the discoveries in all of these directions both at the level of engineering studies and at more advanced levels. It is equally important that research directors and their workers be well aware of the possibilities which they offer. One question which naturally follows is: How can a school form a forester in four or five years and hope to be up to date on the new discoveries in the different scientific fields? It is obvious that this is just not possible. It is thus necessary that they have a certain specialization among the share of forest sciences. The forestry school itself must finally think of offering more than a single option. The first separation to recommend is in the 
general field of silviculture and forest products. In certain schools, one can foresee the option of forest management made in such a way that it prepares a student to be manager of a territory or to follow advance studies in forest science." (Shirley, 1966).

This citation of Shirley is dated June 1966. Is it not significant that the Faculty of Forestry and Geodesy had proposed to the University Counsel more than a year ago that it set up analogous departments to those suggested by Shirley?

These new departments will without doubt scare certain of our colleagues. In order to reassure them, these new departments take into account two factors:

(a) first, the Faculty feels a need to organize itself in order to be of service to the students, who once admitted should be given the chance to train themselves for the society of tomorrow. The authors of the Parent Report on this subject have said:

"It is common to say that the school is made for the infant. This preoccupation of teaching centered upon a child has given rise to an elaborate and active pedagogy. This currently inspires those values which we wish to see honoured at school such as the respect for intelligence, creative ability, the spirit of systematic research at the maternal level and of a basic spirit; this current pedagogy carries with it a spirit and intention that one is not able to find in the secondary teaching and university teaching." (Parent Report Vol. II P. 15)

In other terms, rather than force the students into a single mold, some will now have the possibility of profiting by their intelligence in several different options.

(b) the second factor which favours the development of the new departments is the need for more specialized training such as I previously described. This need is more intense than one would first think.

If one were to listen to forest engineers who have already graduated, it would be necessary to add a large number of courses to the current curriculum. This is one of the results presented at this meeting last year. Also this feeling seems to be general in North American forest education. Dean Garratt of Yale University has told us recently that if he had to add to the curriculum all the wishes of the graduates of the Forestry School, the regular course would have a duration of up to ten years.

Also, the students currently insist upon a lightened program of studies. This again is nothing new and this tendency is confirmed by Dean Garratt. It seems to us that the new organization will permit a justified aeration of the timetable at the same time permitting a more intense specialization. But first let me tell you what these new departments are: (see Table I).

In place of the traditional departments of surveying and of forest engineering, you will note that there will be five departments:

1. ecology and of forest pedology.

2. management of silviculture.

3. logging and wood utilization.

4. geodesy and cartography.

5. photogrammetry. 
The two departments already existing are replaced by two study directions. There is also a service of experimental stations. Eventually it is hoped to establish a cartography service for the whole university campus.

TABLE 1

New Organizational Chart of the Faculty of Forestry and Geodesy

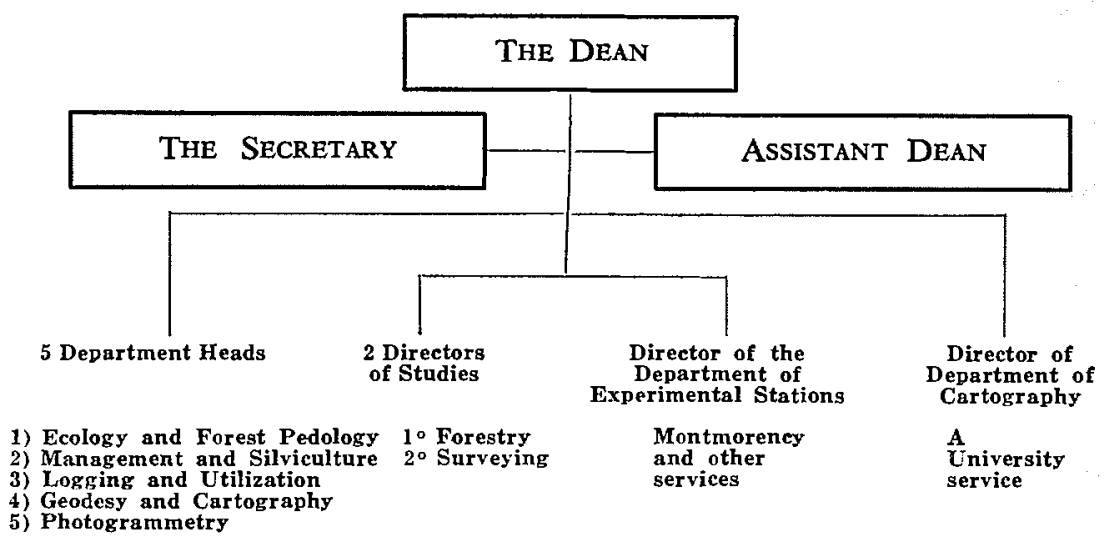

For the moment the five departments constitute centres of interest and research for the professors. They are at the services of the two directions of studies for the regular curriculum, but they are set up mainly for the purposes of post-graduate teaching. It is, however, the desire of the University Counsel that the Faculty in addition to the two bachelor degrees in applied science in forestry and surveying also develop curriculum leading to a B.Sc. in photogrametry and a B.Sc. in forest science and a B.Sc. in geodesic science. It is thus possible that in a few years time there will be graduates in forest science as well as in forestry. One can foresee here and now that the Corporation of Forest Engineers must re-define itself, taking note of these new conditions. This problem does not present itself at the moment since, once again, initially the newly created departments exist primarily for post-graduate study and research starting at the end of regular curriculum. They also serve to orient the regular curriculum in forestry and surveying.

Let's rapidly examine each one of these centres in interest. In ecology and forest soils, the activity is centered around the definition of the forest site. This need to know the milieu has never been more pressing than it is at this moment when one speaks of regional planning. One of our members spoke to this meeting last year as follows:

"Be it at the level of research, or inventory or of silviculture itself the forest engineer must possess a profound knowledge of geology, of geomorphology, of pedology, botany, plant physiology, and climatology, and that's not all." (Lemieux 1965).

This department even if it does not have at its disposal all the people that it would like to have, is nevertheless one of the best furnished. The 
Faculty has been able to recruit men who are authorities in this field and it is thus significant that the number of the registered post-graduate students in this field is very large.

In the second department, interest goes further to management and silviculture. Actually, the center of interest consists in finding the necessary means to insure to the population the greatest possible outcome in our available forest areas. If you look at the sub-titles you will rapidly note that once again the Faculty can offer a well rounded curriculum. The section of economy, in particular, has been given some strong injections in the last few years. This department as well has a rather larger number of registered graduate students. One must recognize that this department constitutes one of the most important sections of forestry activity.

In the third department, that of logging and wood utilization, the Faculty has tried for several years with more or less success to assure the presence of competent personnel and in sufficient number. In exploitation the problem is still a prickly one even if the Faculty has been able to find solutions. Thus not being able to obtain the services of a career professor, certain courses are presently assured by people, on a part time basis, who have made their mark in the field of exploitation. This permits the students to receive teaching given by men intimately acquainted with the problems of exploitation and planning of logging operations.

It is useless to teach logging if the students do not receive the necessary ideas in order to permit them to take decisions and carry out the job. Logging plans must take into account the principles of multiple use and the operations must be carried out at the lowest cost. Management thus becomes of basic importance. It is to this end that emphasis is given in the current teaching of logging.

Also due to the intervention of one of our members, the Canadian Pulp and Paper Association has decided to invite logging professors from the four faculties of forestry in the country to participate in meeting of the Logging Committee. Thus another method is put at the disposal of the students in order to have teaching right up to date.

A comment frequently heard, when it is a question of regional management, concerns the ability of foresters to work as a team with specialists of other professions. On this subject, the line of argument goes so far as to blame the faculties of practically living behind closed doors. Let us look at what is done in this case.

In the first place, the Faculty of Forestry and Geodesy is aware of the danger of "enculture", a phenomenon described by Cowley (1963). This consists of the activities of a professional group seeking the interpretation of the culture in an educational process which imposes a single method of thinking, reflection and questioning. Thus don't be surprised if the Faculty makes use of the assistance of people who have been trained in different schools and who most often speak according to different conceptions. Moreover, exchanges permit that specialized courses can be advantageously given by specialists coming from other departments of the university.

In addition, as some of you have already outlined, it is necessary to 
be sure that there are connections between teaching and practice. I have already said something about practical work in the summer and the part time assistance which is given by certain practicing foresters. I deplore the fact that, for some, this exchange is only in one direction. If there is to be logic in this field, we must admit that career professors in certain fields must be able to refresh themselves in practice when they feel the need.

If you will allow me a few words on the training given by the Faculty at the moment. It occasionally happens that certain students (happily they are in a minority) insist on having only teaching in practical matters based on current technology. You have already had the expressions "Of what use is that? I am not going into production, I have no need of soils, etc. . . ." Such a teaching based upon the first available employment certainly does not constitute a guarantee for the future, particularly when it is a question of planning and management. We know with what speed certain techniques can rapidly be made obsolete. Certain American authors who have studied this problem report that:

"Ordinarily, these same students who are looking for training in practical matters have the least ability to fill positions other than those for which they were prepared. If by chance these people are called to fill administrative and management jobs their technical preparation appears inadequate, particularly when they are asked to resolve the administrative problems related to technology." (McDermott, Fletcher and Mair, 1966.)

Thus, the training must not be based upon techniques and individual species but primarily on the teaching of the basic principles.

The Qualifications

The management of forestry resources is without any doubt the proper role for a forest engineer. He is prepared for this role. But it is not just a question of speaking of forest management alone. Nowadays forest management has great importance in the ranks of regional planning and land management. Allow me to quote the Director General of the FAO, Mr. B. R. Sen (1966):

"It seems clear that the forester's problems have become much more numerous and complex, because the accelerated consumption of all resources that goes with population growth and economic development inevitably brings about a shift of emphasis from resource conservation to resource planning and management. This is particularly true of the renewable resources, on the use of which foresters have a vital say and which are becoming increasingly subjected to more intense, often conflicting, demands."

Further on by the same author:

"Allow me to insist on the role of foresters in planning . . ."

A universal authority such as Dr. Sen thus recognizes that foresters have an important role in planning. Is it sufficient that all the regional planning be the sole competence of foresters? Regional planning is not a specialty in itself, it is a question of level of preoccupation of a number of individuals who first must make a plan of development and then demand or ask various specialists for contribution of their technology to the profit of man, the primary base of the plan. 
We have seen that the training of a forest engineer makes him a specialist within the practise of forestry, that is why Lemieux (1965) stated:

"A forest engineer has a role to play in planning because he knows best the forest and its problems and what this means for their management and exploitation," and further on the author adds:

"At the level of carrying out the works, no one will contest that all that concerns the management of the forest resource for forestry ends is the exclusive domain of the forest engineer. It is equally important, in management, if not exclusive, to take note of other resources closely related to the forest such as wild life and recreation". Although Lemieux, undoubtedly speaking from experience states that:

"The preparation of a plan can perhaps be the work of a multi-disciplinary team ... one should not conclude that in the forestry area for example all the aspects of the forestry problem and of the forest industy are the exclusive property of the forestry engineer. Certain economic and sociological aspects for example are certainly better dealt with by an economist or a sociologist."

In summary, the qualification of a forest engineer to occupy himself with problems of forest management and silviculture in their widest sense is without question. This qualification itself is recognized by law and is explicit in the Code of Practice (Ethics) adopted by the Annual Meeting last year. But in regional planning the engineer becomes one of the specialists in a common aim. Neither superior nor subordinate he must contribute to the management of the overall area. His training renders him capable of contributing as much as the forest and other resources are concerned, but he cannot take the place of an administrator, a sociologist or an economist.

However, this does not prevent the forest engineer from playing a more important role than that which is his normal concern. If he has the personality and the necessary training he can look for more important positions. It is no longer the forest engineer who counts but the individual who is capable of conceiving things on a larger scale. This supplementary formation is particularly necessary at the level of regional planning and land management and it is my feeling that this must be recognized at the level of post graduate study.

The field of practice of a profession cannot be defined on particular cases. It is not because a forest engineer is occupied with protection against fire that protection is a field for a forester. Rather, it is because the forest engineer is prepared to take up protection that the subjects calls for his competence. It is thus necessary to define the qualifications of the profession in function of his training. One should no longer demand the maintenance of the situation which does not correspond to reality. For example, is it not civil engineers who carry out the bulk of the engineering in the forest?

Finally, there will be an eventual arrival on the labor market of bachelors of forest science other than those who graduate in forestry; should not the members of the Corporation undertake a redefinition of the ranks in their Corporation? There is little doubt, in all types of technical and scientific activities that there is a need to make a high level program of university activity. A corporation should agree to modify its ranks if there are professionals of equal and superior qualifications to its members. In other words and by way 
of example, could one imagine that in the name of common good, the Corporation of Forest Engineers refuse admission to its ranks to bachelors in forest science who will be just as competent, if not more so, than those who are currently admitted. I have ignored the legal position, which in any case could not be upheld for a long time in such a situation. I prefer that the problem be regarded positively and that we should seek the most sincere solutions.

Finally, the competence of an engineer must improve as he develops his knowledge. Carrying the title of forest engineer does not immediately render us capable of photo interpretation. It is necessary that each one of us has had the occasion to get some training in this subject. American workers state that graduates of ten years ago cannot compete in value with recent graduates unless they spend at least 10 percent of their time absorbing and learning what has developed since they left university.

In forestry, as in numerous other sectors in the course of the last decade, it is said that the volume or the quantity of scientific literature which has been published is about equal to that which has been published since the beginning of science. One must then think in terms of permanent education. Among the suggestions put forward, some American authors (see McDermott, Fletcher and Mair, 1966) suggest that employers authorize their employees to undertake periods of refreshment which could eventually lead to a sabbatical year. This is a solid indication that the proposition made by the Corporation of Forest Engineers to the Minister of Lands and Forests before the public audiences was not as crazy as some people have thought. As for professional corporations, François (1966) has given them the duty of endeavouring by all possible means, to raise the professional level of their members by setting up services. These corporations must be in close contact with the universities in order to define the immediate and pressing needs of their members. Finally the forest engineer has an obligation towards himself, his employees and the population in general and he must find there the necessary motives in order to return to the sources of learning, because more and more it is the individual who is judged by his work and not the employer or the professional corporation. He must thus continually have a greater ability. The authors of the Parent Report (1965) think that-

"'in the most important sectors of professional activity it is necessary after each period of 5 to 10 years of work to consecrate or set aside a period of some months for retraining."

There is here, you will admit, a real challenge. It is to this challenge that we must address ourselves because of our training as forest engineers and our responsibility towards the forest and the common good of the population.

\section{REFERENCES}

COWLEY, W. H. 1963. Understanding the academic world. In the volume Higher Education in Engineering and Science. McGraw-Hill Book Co., New York.

Faculté de foresterie et de géodésie. Université Laval, 1965. Annuaire 1965-66.

FRANCOIS, T. 1966. Le rôle des assaciations professionnelles forestières. 6th World Forestry Congress.

LEMIEUX, G. 1965. L'ingénieur forestier et la planification. 45e congrès annuel de la Corporation des ingénieurs forestiers de la province de Québec, 45-51. 
McDERMOTT, R. E., FLETCHER, P. W. et MAIR, W. W. 1966. Continuing education in natural resource management. 6th World Forestry Congress.

PARENT, A. M. et al. 1965. Rapport de la Commission royale d'enquête sur l'enseignement dans la province de Québec. Vol. II.

SEN, B. R, 1966. Inaugural address at the beginning of the 6th World Forestry Congress.

SHIRLEY, H. L. 1966. L'enseignement dans le domaine de la forêt et de ses dérivés dans un monde en évolution. 6th World Forestry Congress. 